\title{
The Waqf Empowerment as an Alternative Solution to Overcome Unemployment in West Java
}

\author{
(Study on the Implementation of Entrepreneurship Concept in the Civic Economy)
}

\author{
Prayoga Bestari, Syaifullah Syaifullah \\ Universitas Pendidikan Indonesia \\ Bandung, Indonesia \\ yogabestari@upi.edu
}

\begin{abstract}
One of the implementations of decentralization managed by the regional government is the management of waqf land. Amid the social problems of the Indonesian people and the demands for economic prosperity today, the existence of waqf institutions is very urgent and strategic. The effort to empower waqf land to open employment is one part of the development process by increasing the welfare of the surrounding community. This study uses a qualitative approach. The steps of the research into three phases, namely the preliminary study phase, the development phase, and the reform. In the empowerment of waqf, land to open employment is one part of the development process. Based on the results of the research on entrepreneurship-based land development models of at least 3 types of model 1). Lands Endowments based on The Baitul Mal Wat Tamwil Model (Model of Land Management of Waqf based on Baitul Mal Wat Tamwil), 2). Online Endowments-based Lands Model (Online-based Waqf Land Management Model), 3). Lands Endowments based on Islamic Franchise Model (Sharia-based franchise land management model).
\end{abstract}

Keywords-employment; empowerment; land endowment; waqf

\section{INTRODUCTION}

The dynamics of the government system in Indonesia today have a significant impact on regional development in all corners of the Unitary Republic of Indonesia. One of the effects that are felt at this time is the implementation of the decentralization of several central government affairs that are managed and developed by the regional government. One of the implementations of decentralization managed by the regional government is the management of waqf land. Amid the social problems of the Indonesian people and the demands for economic prosperity today, the existence of waqf institutions is very urgent and strategic. Aside from being an aspect of Islamic teachings with a spiritual dimension, endowments are also teachings that emphasize the importance of economic welfare (social dimension). Therefore, it is very important to redefine waqf so that it has a meaning that is more relevant to the real conditions of welfare issues.

The effort to empower waqf land to open employment is one part of the development process by increasing the welfare of the surrounding community. However, some communities do not yet have an understanding of the management of waqf land, so that many waqf lands are not productive. In addition, the waqf land which is actually owned by the people is used by people who are not entitled to enrich themselves. The community as landowners and managers must be able to empower the waqf land to be useful and can be felt by everyone, one of them is by empowering the waqf land to become a business entity that is directly held by the government by appointing managers who are able to develop it.

Based on the description above, the effort to empower waqf land to open employment is one part of the development process by increasing the welfare of the surrounding community. There are so many waqf lands that can be empowered for new jobs such as business, recreation, trade and so on with the management of waqf land. From the overall function of the waqf land, lately, it seems that not all of it has been cultivated or empowered.

\section{LITERATURE REVIEW}

In everyday life, we often hear the word waqf. Judging from the terminology, waqf can be said to be $A l-h a b s$, which is an understanding of language derived from the verb habasayahbisu-habsan which means to distance people from something or imprison which then develops into habbasa which means to endow wealth due to Allah. While the word waqf itself comes from the verb waqata (fil madi)-yaqifu (fiil mudari)-waqdan (isim masdar) which means to stop or stand [1]. In Arabic, the word waqf is waqf and has synonyms of habs. Both of these words are nouns derived from the verb wakafa and habasa. As for the plural, waqf is awqaf and habs are ahbas. The difference in the use of the word waqf and habs depends on the area and school that is adopted. Habs and ahbas are usually used in North Africa among followers of the Maliki school [2].

In the Presidential Instruction No. 1 of 1991 concerning Compilation of Islamic Law (KHI) article 251 paragraph 1 states that the waqf is a legal act of a person or group of people or legal entities that separate some of their objects and institutionalize them forever for the sake of worship or other general purposes in accordance with the teachings Islam. Based on the understanding of waqf above, it can be said that waqf is a legal act that is legal, holy and noble. In addition, the benefits of endowments can be used continuously, for those 
endowments are also known as almsgiving, which is worship that gives rewards that continue to flow even though the benefactor has died. Based on some of the notions that have been explained previously, that waqf is a form of worship carried out by honoring from Allah SWT by holding a property that has economic potential that can be utilized continuously or within a certain period of time so as to improve the welfare of the people. Waqf or alms is a worship that has a great reward, so it is unfortunate if the person who does waqf there is still a sense of riya in his heart coupled with not expecting the pleasure of Allah SWT [3].

According to the Ulum jumhur, waqf is an activity of detention of property that is likely to be useful by its owner by allowing the body to remain eternal and not transferred to its relatives or to other parties [4]. Whereas Sayyid Sabiq defines waqf as the detention of property and takes advantage of the assets held for the way of Allah, or withholding property that might be benefited without damaging or spending the material itself and used for virtue [4]. According to Wadjdy in an economic perspective, endowments can be defined as [5]:

Transfer of funds (from other assets) from consumption needs and invest them in productive assets that generate income for future consumption by individuals and groups.

Karim separately, from basically the target, basically waqf in the form, namely [4]:

- endowments are given to family and close relatives or certain people, called waqf al-Ahliy or waqf al-dzurry. The target is a particular person or community whose motivation is not to advance Islam,

- endowments for virtue in order to get closer to Allah called the alal-khairy waqf.

Waqf administrators in figh literature are called nadzir or mutawalli, namely people or bodies that hold the mandate to maintain and manage waqf assets as well as possible in accordance with their form and purpose [5]. Looking at Nazhir's understanding above, both etymologically and in terminology, the nadzir profession must be professional. Further Shafi'i Antonio underlines that in order to be able to manage waqf professionally there are at least 3 (three) basic philosophies that must be emphasized, especially when we want to empower waqf productively [5]:

- the management pattern must be in the frame of "Integrated Project" not parts of separate costs, waqf funds will be allocated to empowerment programs with all kinds of costs included in it,

- the principle of welfare of Nadzir. It is common knowledge that the nadzir profession is not a professional profession and even the nadzir works carelessly or even the work of Lillahi ta'ala who does not demand work time, professionalism, proper payroll, and so on. As a result, the work of the nadzir is chaotic as it is today,
- principles of transparency and acountability where nadzir must report annually the process of managing funds to the ummah in the form of an audited financial report including the fairness of each post.

The presence of Nadzir as a party given in managing waqf assets is very important. Even though in classical or contemporary fikh, there is no nadzir as one of the pillars of waqf, but the scholars agree that waif must appoint nadzir waqf, both individuals, and institutions. It is common knowledge that the managers who are unprofessional and capable or who do not have adequate abilities assets do not function optimally, and even become a management burden for the entrepreneurs and make the property as a junk not neglected that does not benefit at all.

The understanding of empowerment according to Suharto in his book building the People's Community, as follows:

Empowerment is a process and purpose. As a process, empowerment is a series of activities to revive the soul or empowerment of weak groups. As a goal, empowerment is a reference in the place or outcome desired by social [6].

The definition above is that the empowerment of products carried out to improve the capacity of the community is stronger in the protection of activities provided by the local government. Community empowerment is a concept of economic development that summarizes social values. This concept reflects the new paradigm of development, namely those that are "people-centered, participatory, empowering, and sustainable" [7]. This concept is broader than just eye-fulfilling basic needs or providing further purification processes (safety nets), which addresses it as the development of seeking alternatives to concepts in the past. The concept that evolved from various efforts and practices to find something else by Friedman (1992) is called alternative development, which requires 'inclusive democracy, appropriate economic growth, gender equality and equality between generations' [9].

\section{METhODOLOGY}

This study uses a qualitative approach. The steps of the research into three phases, namely the preliminary study phase, the development phase, and the reform [8]. Preliminary Study, which is the preparation stage for the model. At this stage of literature studies, field surveys and initial product manufacturing are carried out. The literature study that has been carried out is studying the nature of waqf land. Field survey that will be carried out by the Department of Land and the Department of Religion in West Java. The results of the introduction are data on waqf land that can be developed as land for employment.

Study of development, to issue information regarding the location, status, area, and location of the general location of the waqf land. Testing studies carried out through experiments at different research locations. The way to do the step reversal process. In the preliminary and development stage, activities are carried out related to the process of formulating types of employment. In the testing phase, the development of the type of work of the condition of the suitability of the waqf 
conditions with the type of employment to be opened. After that, proof of the improved score has been made.

Then the discussion is done systematically based on the formulation of the predetermined problem. Before conducting the discussion, the results of data collection obtained through interview, observation and documentation techniques were analyzed using the Miles and Huberman model. The technical analysis consists of data reduction, data presentation, and data verification. The data obtained was then validated using source triangulation techniques and data COLLECTION techniques [10].

\section{RESULT AND DISCUSSION}

Based on the results of research that has been done, both the results of interviews with the Regional Office of the Ministry of Religion in West Java, the results of the study can also be obtained information on the extent and extent of waqf land. Basically, the Ministry of Religion of the Republic of Indonesia has made the application become a database of endowments throughout Indonesia. The application makes to collect and record the amount of waqf land in all regions in Indonesia. The application is named as the Waqf Information System (SIWAK) which in this case is managed by the Ministry of Religion of the Republic of Indonesia. In order to be able to use the data in the regions, the SIWAK application is integrated with the regional offices of the Ministry of Trade in the Province and in the Regencies/Cities.

The functions of the SIWAK include information media for the general public regarding waqf land data throughout Indonesia. However, the current problems in the field, data collection of waqf land through SIWAK has not run optimally. This is because the manual data collection of waqf is blank in the area so that there are still many lands that have not been identified. In addition, the weaknesses of the information system only contain information about the number and extent, while the information on its utilization has not been disclosed. With an area of $35,222.8 \mathrm{~km} 2$, the potential for waqf land is very large and strategic. Based on the SIWAK data accessed on July 27, 2017, West Java has a total of 62,515 waqf locations with a total area of 6,038.56 [Ha] spread across 27 city districts. The following are data waqf in West Java based on SIWAK data as of July 27, 2017.

Based on research that has been done by researchers regarding waqf land in West Java Province, especially in Bandung Regency, Bandung City, Cimahi City, West Bandung District, Sumedang Regency, Subang Regency, Garut Regency, Tasikmalaya Regency and Tasikmalaya City, it can be explained that land empowerment efforts waqf to open employment is one part of the development process by increasing the welfare of the surrounding community. There are so many waqf lands that can be empowered for new jobs such as business, recreation, trade and so on with the management of waqf land. From the overall function of the waqf land, lately it seems that not all of it has been cultivated or empowered. These lands tend to be consumptive and not maintained without clear benefits or functions. Behind that reality, with intense competition, people are starting to run out of ideas to find new business fields.
However, because of the lack of capabilities, they are unable to compete with others who are higher in education. With the utilization of existing wealth, we can anticipate the lack of employment with the management of waqf land in the form of land to be empowered, one of them as employment. And that can be seen from the results of observations as well as observation of researcher in several districts, especially in West Java. The following is an overview of employment opportunities that can be developed through empowerment of waqf land in West Java.

This section will discuss the empowering productive waqf land. The empowerment model in question is a system that regulates the management of land waqf based on Islamic entrepreneurship that is a concept of waqf land itself. Some of the empowerment models are as follows:

\section{A. Lands Endowments based The Baitul Mal Wat Tamwil Model}

Thiis model is one of the principles of the principles of Islamic sharia in it such as the Baitul Mal Wat Tamwil. In principle, Baitul Mal Wat Tamwil is a microfinance institution that operates through Islamic principles. BMT as the name implies consists of two functions. First, Baitut Tamwil (property development house), which is capable of carrying out activities to develop productive businesses and activities in improving economic quality and activities to save and support financing of economic activities.

Secondly, Baitul Maal (house of wealth), receives funds from zakat, infaq and alms and optimizes its distribution in accordance with the regulations and mandates.

It can be explained by the BMT-based land management model. First, there is a need for a professional manner. This is a basic management process that can be carried out. Because professional training can be shown in organized management in accordance with the provisions of Islamic Shari'a and the applicable legislation. In addition, in the current era of bureaucratic reform, administrative completeness is the absolute requirement for the implementation of a professional activity that will have the effect of sources of income/funds for the development of the program implemented.

Second, the nadzir who has formed professionally then formed Baitul Maal Wat Tamwil as the implementing body for the management of productive waqf land. However, in its implementation, it remains under the supervision of Nadzir as the main person in charge of the management of waqf land. In addition, Nadzir, in this case, serves as a determinant of the criteria for land to be used as a business land. Furthermore, Nadzir also as the manager of waqf land functions as a financial audit body, which in this case monitors the circulation of profits from each business, grants from members of BMT, financial assistance from the government to the order to remain in the path of Islamic law and legislation apply.

Third, after the approval of Nadzir, BMT can open business land based on the criteria of available waqf land. This can be used by BMT to 1) make acceptance of members for people in need; 2) investor acceptance; 3) opening employment opportunities according to the specified fields; 4) managing the 
financed generated or excluded from the implementation of each type of business; 5) dividing profits for each member based on the provisions of Islamic Shari'a and the prevailing laws; and 6) through the types of businesses that are developed at affordable prices.

Fourth, after walking normally BMT can develop other types of businesses that are considered in accordance with the criteria of waqf land. In addition, the objectives carried out in the use of land are solely to help the welfare of the community, as wakif mandates to Nadzir that the values of worship for all stakeholders are maintained, especially for the waqf who have endowed their land. for the benefit of the people.

\section{B. Lands Endowments based Online Model}

In the context of waqf land management, the use of online businesses can be used as innovations for business development. However, in this case, business activities carried out online are not solely seeking profit. The development of this kind of model is done by collecting waqf land $n a d z$ who are not productive and waqf landowners who are managed by a web-based community, in this case, an integrated and verified web system by the Ministry of Religion's web system. Management of online-based waqf land is used as a medium to facilitate the public in accessing the fulfillment of needs and employment opportunities that utilize land of waqf land by Nadzir. The focus that is prioritized in this online-based waqf land management model is to invite the nadzir and the benefactors to be able to use waqf land to be productive which involves the role of the West Java Ministry of Religion Regional Office. In practice, the West Java Ministry of Religion Regional Office can form a special team as a web manager whose job is to provide access online by opening up opportunities for nadzir and the benefactors to be able to make their waqf land as business land that has been professionally administered.

It can be obtained from some information about the land management model based on online applications. First, the online application that is intended in the management model of productive waqf land is an application developed as 1) collectors of nadzhir and benefactors; 2) means of information concerning data on productive waqf land; 3) information on waqf land that can be used as employment opportunities for people in need. Second, the online application of productive land rights is managed by independent and professional institutions that function as web-based waqf land managers. The way it works, the manager of this application is land productively, but the web manager does not have the authority to directly manage waqf land. Furthermore, the web manager is only responsible for recruitment of people who have not worked on the types of businesses provided by Nadzir. In addition, productive waqf web managers help legalize the types of businesses managed by Nadzir to the Ministry of RI. Therefore, there is a need to be an integrated network between online-based waqf land portal and the Indonesian Ministry of Religion's SIWAK website.

Third, the online application of land rights will be expected to provide information on productive land in a professional manner through the use of business land for people in need/unemployment as well as becoming a recruitment media that will be channeled to types of businesses managed by Nadzir. This Web application can be applied in all District / City Regional Office of Religion Office.

\section{Lands Endowments based Islamic Franchise Model}

This model of land management adopts a franchise business model which in this case is carried out based on Islamic Sharia, especially by not eliminating the functions and intentions of the waqf land itself. the third model in the management of productive land use franchise-based land use. However, the concept is not necessarily adopted as a whole, but integrated with Islamic provisions. In principle, this Lands Endowments based on Islamic Franchise Model (Sharia franchise-based land management model) puts forward the opening of employment opportunities by each nadzhir. More specifically, the nadzhir who develops a business through waqf land that provides opportunities for needy/unemployed people to manage the type of business.

Based on the franchise-based, some information can be obtained. First, this kind of model requires a policy from the government, in this case, the Ministry of Religion in order to be able to provide guidance to several nadzir as a project of entrepreneurship-based waqf pilots. Because there are still many nadzirs today who have difficulty developing productive waqf land into businesses that can create jobs. This is necessary so that productive waqf land can be used as a business land that can benefit the welfare of the community.

Second, after the formation of the nadzir pilot project that developed the type of business, the nadzir can recruit unemployed people in the surrounding area to work to run the business. Meanwhile, the business is carried out needs to be developed so that it can open similar and non-similar business branches. In addition, after developing it does not rule out the possibility of being able to attract the benefactors to channel their waqf land to the nadzir to later be developed into the business land. So that later it is expected that the nadzir can have similar or similar types of business from the development of the business land.

Third, the nadzir position in this model is as the manager of the road various types of businesses are developed. In addition to opening jobs, nadzir can also provide opportunities for other communities who need to manage their own business but in ownership and the profits obtained continue to enter Nadzir. The concept of franchising like this is adopted in sharia so that the management of waqf land continues to run according to its intentions and functions and is able to provide broad employment opportunities for the surrounding community. Therefore, in this model, a strong synergy between nadzir and the government is needed in order to be able to run as expected while still observing Islamic law and the prevailing laws.

\section{CONCLUSION}

In the empowerment of waqf, land to open employment is one part of the development process. Lots of waqf land that can be empowered for new jobs such as business, recreation, trade and so on with the management of the waqf land is expected to be able to minimize unemployment, especially in West Java. 
The productive empowerment program of waqf, which is still considered to have not reached the maximum word, because there are several factors including 1). Lack of Community Knowledge and Skills, 2). Lack of Attention from the Government, 3). Education, 4). Lack of capital, some of these factors are obstacles to empowering land productively. Another problem lies in Nazhir especially as a person who is directly mandated by the waqf to manage waqf productively, accountable, and transparently it can be said that it is still less than optimal in producing land productively. The empowerment model of waqf land that is in line with the values of Islamic entrepreneurship and sharia. Based on the results of the research on entrepreneurship-based land development models of at least 3 types of model 1). Lands Endowments based on The Baitul Mal Wat Tamwil Model (Model of Land Management of Waqf based on Baitul Mal Wat Tamwil), 2). Online Endowments-based Lands Model (Online-based Waqf Land Management Model), 3). Lands Endowments based on Islamic Franchise Model (Sharia-based franchise land management model).

\section{REFERENCES}

[1] S. Kartika, Pengantar Hukum Zakat dan Wakaf. Jakarta: Grasindo, 2006.

[2] M.D. Ali, Sistem Ekonomi Islam Zakat dan Wakaf. Jakarta: UI Press, 1988 .

[3] Instruksi Presiden Nomor 1 Tahun 1991 tentang Kompilasi Hukum Islam (KHI).

[4] H. Karim, Fiqih Muamalah. Jakarta: Raja Grafindo Persada, 2002

[5] F. Wadjdy and Mursyid, Wakaf Untuk Kesejahteraan Umat. Yogyakarta: Pustaka Pelajar, 2007.

[6] E. Suharto, Membangun Masyarakat Memberdayakan Rakyat. Bandung: PT Refika Aditama, 2010.

[7] R. Chambers, Rural development: putting the last first. London; New York: Longman, 1985.

[8] Sukmadinata, Metode Penelitian Pendidikan. Remaja Rosdakarya: Bandung, 2005.

[9] G. Kartasasmita, Pembangunan Untuk Rakyat: Memadukan Pertumbuhan dan Pemerataan. Jakarta. CIDES, 2000.

[10] M.B. Milles and Huberman. Analisis Data Kualitatif, Buku sumber tentang metode-metode baru. Jakarta: Universitas Indonesia Press, 2007. 